\title{
Brief Discussion on Auditing of Tender Documents for Construction Projects
}

\author{
Yunhua Liu \\ Beijing Jiaotong University \\ Beijing, China \\ Yhliu1@bjtu.edu.cn
}

\begin{abstract}
The tender process, which is to procure an outstanding contractor, ensure the construction quality and control the construction investment, is an important step in the process of construction project management. The paper proposes conducting an audit on the tender documents. Through the conventional engineering audit and carry out the tender document engineering audit comparison, expounds the necessity of audit tendering documents. In the audit of the tender documents, using the checklist approach proposed should focus on the following contents: definition of the scope of the tender, quality and construction duration requirements, division of the rights and responsibilities between the contractor and employer, specific requirements for technical standards, preparation and review of bill of quantities, legally compliant approaches to resolve disputes. Finally draw the conclusion that in order to raise the level of project management, Doing the bidding documents audit should take the following measures: establishment of a sound system, support is required from the employer and coordination is necessary from relevant departments, selection of whole process audit agencies with high comprehensive qualities, planning in advance and development of specific plans, improving capabilities and quality of internal audit staff of employer.
\end{abstract}

Keywords-

Construction;Engineering;management,; auditing;tender documents; $B O Q$

\section{INTRODUCTION}

At current stage, the whole process audit is being conducted on construction projects. However, in most cases, the audit is only applied to the review of variation and negotiation, concealed work and project payments during the construction stage and the early stage involvement is rarely performed. In order to take better advantage of the whole process audit, the early stage involvement of audit department is necessary when the designers are selected. The audit is required to be carried out on the contractor during the tender process, from the review of the design drawings. The early-stage involvement of audit is expected to achieve good economic results in the course of auditing.

\section{NECESSITY OF AUDIT ON TENDER DOCUMENTS}

The preparation of the tender documents is an important step in the tender process. At present, authorization by the employer of a procuratorial agency to carry out the tender is prevalent. The procuratorial agency would use format text in the preparation of the tender documents and follow the same pattern in standards and requirements without targeting specific construction projects. The replacement of the project name in the tender documents for other projects frequently occurs. As a result, the tender documents prepared under such a case run against the guideline of precision, meticulous and correctness.

In order to improve the quality of tender documents, audit on the tender documents is essential. Upon the completion of the tender documents by the procuratorial agency, the whole process audit personnel should carry out the audit to ensure the precision of tender documents, the rationality, completeness and accuracy of the bill of quantities, and the tender control price in conformity with the actual project, thereby providing a basis for tenderers to submit tenders, and for future project management and cost control.

Table 1: the comparison of general audit and the whole process audit of audit content

\begin{tabular}{c|c|c}
\hline $\begin{array}{c}\text { The audit } \\
\text { form }\end{array}$ & The general audit & $\begin{array}{c}\text { The whole process } \\
\text { audit }\end{array}$ \\
\hline \multirow{4}{*}{$\begin{array}{c}\text { The audit } \\
\text { content }\end{array}$} & advance payment & bills of quantities \\
\cline { 2 - 3 } & interim payment & tender sum limit \\
\cline { 2 - 3 } & $\begin{array}{c}\text { adjustment in } \\
\text { contract sum }\end{array}$ & tender documents \\
\cline { 2 - 3 } & variation order & tender sum \\
\cline { 2 - 3 } & final account & contract sum \\
\cline { 2 - 3 } & & advance payment \\
\cline { 2 - 3 } & & $\begin{array}{c}\text { interim payment } \\
\text { contract sum }\end{array}$ \\
\hline & & $\begin{array}{c}\text { measurement of } \\
\text { quantities }\end{array}$ \\
\cline { 2 - 3 } & & site instruction \\
\cline { 2 - 3 } & & variation order \\
\cline { 2 - 3 } & & final account \\
\hline
\end{tabular}

III. KEY AREAS OF TENDER DOCUMENTS THAT REQUIRE AUDITING

During the audit of the tender documents, examination on the key areas of the format text should be stressed and special attention should be paid to the auditing of the particular conditions thereof.

A. Review of the tender documents

Prior to the review, the whole process audit agency 
should carefully review the drawings in the tender documents, point out any discrepancies and propose reasonable suggestions to the finishing standard and finishing materials. Based on this, the tender documents will be further reviewed to ensure the legal compliance of the documents, and the conformity of the actual situation of the project and substantial requirements of the employer. The review should address the following issues:

1) Definition of the scope of the tender. The accurate scope definition not only provides a guideline to the scope of BOQ preparation, but also acts on the determination of specialty subcontracting with provisional valuation.

2) Quality and construction duration requirements. The appropriate quality requirements decide the quality of construction projects, and reflect the individualized requirements on construction products required by the employer. The construction period requirements determine the construction time frame of the construction product and decide accelerated construction measures.

3) Division of the rights and responsibilities between the contractor and employer. The legal compliance and completeness of the rights and responsibilities provide the basis for later construction management and disputes settlement and are the foundation for the protection of the rights of both parties.

4) Specific requirements for technical standards. The completeness and accuracy of the technical standard requirements are conducive to the preparation of bill of quantities and the tender documents and would provide guidance on the future construction.

5) Proportion and due date of project payments. The project payments would determine the progress of the project, the investment for safety measures and reasonable organization of the construction process.

6) Principle of variation and price adjustment in the risk range. This principle determines the implementation process of variation and price adjustment in the risk range, and further decides the cost calculation in terms of variation and price adjustment in the risk range.

7) Legally compliant approaches to resolve disputes.

\section{B. Preparation and review of bill of quantities}

The government requires that employers be responsible for the accuracy of bill of quantities. The release of accurate bill of quantities is a key factor to measure the tender quality. Preparation of the bill of quantities covers a wide range of issues, from the calculation rules for sub-items in the bill of quantities, compiling principle of coding, key points of the description of project characteristics, measurement units for sub-items, to work content description. This is the major laborious work in the tender stage. During the review of the bill of quantities, the "Code of Valuation with Bill of Quantities for Construction Works", tender drawings and relevant technology standards should be followed to conclude exact quantities with correct use of calculation rules, to ensure the coding and units of measurement in conformity with the provisions, project measures in line with project reality and to provide precise and complete project characteristics and project description.
Table 2: The weight of each item, when auditing the bills of quantities

\begin{tabular}{c|c|c}
\hline NO & The audit content & Weight \\
\hline 1 & quantities & 0.3 \\
\hline 2 & item code & 0.1 \\
\hline 3 & units of measurement & 0.1 \\
\hline 4 & item description & 0.3 \\
\hline
\end{tabular}

C. Preparation and review project base price or tender control price

At the current stage, the tender control price is applied in the construction market in China to control the tender price. The employer would announce its tender control price when releasing the tender documents. The tender control price is the ceiling price that is derived from the valuation basis and methods issued by the competent construction authorities at the national or provincial level, the proposed tender documents and the bill of quantities, in combination with the specific projects. The tender control price, compared with the project base price, is more effective in avoiding bidding up prices. However, the disadvantage of the tender control price is that the tenderer may file complaints to the tender supervision departments or project cost control departments when the tender control price is set low. A tenderer may as well submit a bid with the price close to the control price if the control price is high. The accuracy of the tender control price is vital to control project investment. During the whole process audit, the preparation and review of the tender control price should be addressed. The audit consulting agency may prepare its tender control price while the procuratorial agency does the same. The tender control prices from both the audit consulting agency and procuratorial agency will then be examined by two organizations recruited by the employer. A final tender control price will be issued upon the examination. The audit consulting agency may as well review the price and issues the final tender control price after the procuratorial agency prepares its tender control price. During the tender process, the employer is required to review the price to see if it complies with the reality of the project. The tender control price derived from this process will be more likely approved by the employer and will be more conducive to the future project management.

Tender sum limit Use the following formula:

$$
\begin{aligned}
& \mathrm{T}=\mathrm{Q} \times \mathrm{U} \\
& \mathrm{U}=\mathrm{L}+\mathrm{M}_{1}+\mathrm{M}_{2}+\mathrm{P}+\mathrm{M}_{3}+\mathrm{S}+\mathrm{P}+\mathrm{T}+\mathrm{R}
\end{aligned}
$$

Where

$\mathrm{T}$ is the tender sum limit;

$\mathrm{Q}$ is the bills of quantities for tendering;

$\mathrm{U}$ is the all-in unit rate;

$\mathrm{L}$ is the labour costs;

$\mathrm{M}_{1}$ is the material costs;

$\mathrm{M}_{2}$ is the machinery costs;

$\mathrm{P}$ is the preliminaries costs;

$\mathrm{M}_{3}$ is the management fee;

$\mathrm{S}$ is the statutory fee;

$\mathrm{P}$ is the profit; 
$\mathrm{T}$ is the tax;

$\mathrm{R}$ is the risk allowance.

\section{ISSUES FOR ATTENTION DURING REVIEW OF TENDER DOCUMENTS}

\section{A. Establishment of a sound system.}

A sound audit system is an important basis to regulate audit actions is an important guarantee for necessary implementation of the audit work.

The development of audit system should be systematic and a guiding document should be drafted for the system, where specific rights and obligations should be defined for executives and specific audit staff. With regard to the audit system for construction projects, the responsibilities of various departments, and their corresponding liabilities, once there is dereliction, should be specified. The audit process for the tender documents should be developed under the guidance of the guiding document. Based on the audit process, the implementation guidelines should be formulated. While the audit system is under improvement, a risk analysis sheet and the specific breakdown of items should be established with respect to the audit of the tender documents. Contents outlined in the analysis sheet should be focused on during the audit.

\section{B. Support is required from the employer and coordination is necessary from relevant departments.}

It requires the support of the senior executives of the employer during the auditing process on the tender documents, which is a precondition for the audit of tender documents. In addition, the support of relevant departments should be obtained. During the audit process, it is crucial for the audit department to hold meetings to communicate and coordinate with relevant departments, which will improve the efficiency and quality of audit work.

\section{Selection of whole process audit agencies with high comprehensive qualities.}

As the audit on the tender documents depends on the whole process audit agencies, the selection of high quality whole process audit agencies is essential. During the selection, what needs to be addressed is the team members who will perform the audit work, rather than the qualifications and performance of the audit agency. The ability and comprehensive qualifications of the team leader play a key role in the successful audit work. Although it is difficult to know the ability and qualifications of the audit team members, it would be an effective way to understand the results of the work performance of the team members, to find out whether they have found potential problems in their past work and whether their audit suggestions were full, reasonable and compliant.

\section{Planning in advance and development of specific plans.}

Audit of the tender documents covers a wide range of issues and it is important to establish a sound plan. The plan should receive approval from the construction project management department. With this plan, during the audit of the tender documents, the relations among various departments can be established and the quality of the tender documents will be ensured.

From the preparation of the tender documents to their release, only dozens of days would be available. Time is not enough if the audit is carried out after the completion of the preparation of the tender documents (including BOQ and the control price). Therefore, specific implementation scheme should be determined before the tender invitation begins. The audit scheme may be decided with audit department of the employer drafting the scheme with the review of different departments, or the scheme may be determined after being drafted by the whole process audit agency authorized by the employer, and being reviewed and approved by different departments of the employer. Documentary content in the tender documents, such as instruction to bidders, technical standards, the terms of the contract, the bid format, should be audited through the way of examination. While the audit of BOQ and tender control price should be conducted through separate preparation of $\mathrm{BOQ}$ and control price by whole audit process audit agency and procuratorial agencies. During the preparation process, BOQ should be verified after the completion of the BOQ preparation to ensure that the tender control price of the audit process audit agency and procuratorial agencies is based on the same BOQ. A perfect audit scheme not only ensures clear responsibilities of the departments during the audit of the tender documents but also successful implementation of the audit, without affecting the release of the tender documents.

\section{E. Improving capabilities and quality of internal audit staff of employer}

Regarding the audit of tender documents, the participation of the internal audit staff is necessary although a major part of the audit work is done by the whole process audit agency authorized by the employer. As internal audit personnel are more familiar with the actual situation of the project, their participation will ensure the preparation of tender documents in line with the specific project situation. Particularly, the role of the internal audit staff is prominent in the preparation of BOQ and tender control price. In the case of a residential building project located in the center of the dependent residential area of an employer, during the audit of detailed measure program of the $\mathrm{BOQ}$, the internal auditors proposed that the measure program include noise isolation and protection of pavement with underground pipeline. With the reminder of the internal audit staff, the measure program of the project has met the actual project situation. With the support of internal audit staff, the audit of the tender documents can be completed successfully and the quality of the tender documents will be ensured. Currently, the internal audit staff of most enterprises is not fully competent for the audit work for the tender documents. In order to improve the capabilities and quality of internal audit staff, the following steps should be taken:

1) Tightening control in the recruitment of audit team

The audit staffs is required to be well-educated, have a strong sense of professionalism, strong sense of responsibility, have solid professional knowledge and 
certain working experience.

The choice of personnel can use the following formula: $\mathrm{S}=\mathrm{R} \times 50 \%+\mathrm{E} \times 20 \%+\mathrm{S} \times 20 \%+\mathrm{W} \times 10 \%$

Where

$\mathrm{S}$ is the personnel evaluation score;

$\mathrm{R}$ is the Personal responsibility;

$\mathrm{E}$ is the Personal education;

$\mathrm{S}$ is the personnel subject or field of study;

$\mathrm{W}$ is the personnel Work experience;

$50 \%, 20 \%, 20 \%, 10 \%$ is the weights of four indexes.

\section{2) Strengthening theoretical study}

Specific measures should be released to promote and encourage internal audit staff to strengthen theoretical study.

3) Strengthening on-the-job training and further education

The internal audit work involves a wide range of content and scope. Audit staff are required to have a good command of legal, financial and engineering knowledge. It is essential to strengthen the post training and continuous education for internal audit staff for the successful performance of the audit work. Enterprises should organize internal audit personnel to receive training and education based on the actual audit needs of enterprises. The training and education can be conducted in a variety of forms so that the internal audit personnel can master the theory and exchange their rich work experience and adapt themselves to audit work development and the needs of the enterprise.

\section{4) Establishing post responsibility system}

The post responsibility system should be applied to internal audit personnel to define their responsibilities, rights and interests, and to establish a mechanism of competition, to reward the internal audit personnel who have made contributions and eliminate those unqualified personnel.

\section{REFERENCES}

[1] Zhao J, Study on Evolution and Application of Risk-oriented Audit, Research on Economics and Management 9, 82-85(2008)

[2] James D Cashell, George R Aldhizer III, Construction Contract Auditing in Local Government Entities [J], The Journal of Government Financial Management, 2004(53),P42-50

[3] The Ministry of Housing and Urban-Rural Development of the People's Republic of China: GB50500-2008 code of bills of quantities and valuation for construction works. China Planning Press, Beijing (2008) "in Chinese"

[4] The Ministry of Housing and Urban-Rural Development of the People's Republic of China: GB50500-2013 code of bills of quantities and valuation for construction works. China Planning Press, Beijing (2013) "in Chinese"

[5] Dirk Donath. Integrated architectural survey and planning Methods and tools for recording and adjusting building survey data. Automation in Construction 16(2007)19-27

[6] Paymond N.Nkado.Forecasting Construction Time By Quantiye Surveying Practics In South Africa. Arban Forum, 1999

[7] Chen.L. Application of Risk-oriented Audit Judging from the Evolution of Audit Patterns. Contemprary Finance \& Economics 6,122-124(2006)

[8] Qiping Shen. The use of information technology by the quantity surveying profession in Hong Kong..International Joumal of Project Management 25(2007134-142)

[9] Kimberly A. Audit Firm Industry Specialization and Client Disclosure Quality. Review of Accounting Studies,9,35-58,2004

[10] Balsam S. Auditor Industry Specialization and the Earnings Response Coefficient. Auditing: A Journal of Practice and Theory,22,71-97,2003 